\title{
Influence of high density planting and spatial arrangement on growth and development in Musa AAA Simmonds
}

\section{Influencia de altas densidades de siembra y distribución espacial sobre el crecimiento y desarrollo en Musa AAA Simmonds}

\author{
José Luis Barrera ${ }^{1 *}$; José Régulo Cartagena ${ }^{2}$; Omar Nanclares ${ }^{3}$
}

\begin{abstract}
1Agronomical Engineer, M.Sc. Universidad de Córdoba. Montería - Córdoba, Colombia; e-mail: jlbarrera@correo.unicordoba.edu.co; (D) https://orcid.org/00000001-9104-0099

${ }^{2}$ Agronomical Engineer, Ph.D. Universidad Nacional de Colombia, Medellín Campus, Facultad de Ciencias Agrarias, Departamento de Agronomía. Medellín Antioquia, Colombia; e-mail: jrcartag@unal.edu.co; (D) https://orcid.org/0000-0001-6196-2439
\end{abstract}

${ }^{3}$ Agronomical Engineer, M.Sc. Universidad de Córdoba. Montería - Córdoba, Colombia; (D) https://orcid.org/0000-0002-9843-934X

*corresponding author: jlbarrera@correo.unicordoba.edu.co

How to cite: Barrera, J.L.; Cartagena, J.R.; Nanclares, O. 2021. Influence of high density planting and spatial arrangement on growth and development in Musa AAA Simmonds. Rev. U.D.C.A Act. \& Div. Cient. 24(1):e1312. http://doi.org/10.31910/rudca.v24.n1.2021.1312

Open access article published by Revista U.D.C.A Actualidad \& Divulgación Científica, under Creative Commons License CC BY-NC 4.0

Official publication of the Universidad de Ciencias Aplicadas y Ambientales U.D.C.A, University, Accredited as a High-Quality Institution by the Colombian Ministry of Education.

Received: February 8, $2019 \quad$ Accepted: April 12, $2021 \quad$ Edited by: Ingeborg Zenner de Polanía

\begin{abstract}
Banana is after apple, the most consumed fruit in the world for its nutritional contribution. Given its importance, it is necessary to advance in the development of agronomic management strategies that contribute to increase productivity and offer alternatives to regulate the consequences derived from the seasonality of production in the Urabá area (Colombia). For this, the clone Williams (Musa AAA Simmonds), at different planting densities (2000, 2500, 3000 and 3500 plants $\mathrm{ha}^{-1}$ ), different population arrangements (triangle, rectangle and double furrow), compared with a relative control (1700 plants ha ${ }^{-1}$ in triangle) was evaluated. The design used was randomized complete blocks in factorial arrangement of $4 \times 3+1$ (densities $\mathrm{x}$ arrays + control). The variables height and perimeter of the pseudostem, number of leaves from planting to harvest, leaf
\end{abstract}

area index (IAF), light extinction coefficient, number of suckers and developmental stages (days elapsed after flowering and harvest) were determined. An analysis of general variance was carried out and another one excluding the control. The Tukey test $(\mathrm{P}<0.05)$ was applied to the qualitative variables and contrasts of orthogonal polynomials were made to test the linear and quadratic effects of the population density factor. The results indicated that the high planting densities and the population arrangements had a negative effect on the perimeter of the pseudostem and the height of the main sucker, favored the LAI, influenced the extinction coefficient, but did not affect the development of the plants.

Keywords: Banana; Light interception; Plant competition; Plant population. 


\section{RESUMEN}

El banano es después de la manzana la fruta más consumida en el mundo, por su aporte nutricional. Dada su importancia, se requiere avanzar en el desarrollo de estrategias de manejo agronómico, que contribuyan a incrementar la productividad y ofrezcan alternativas para regular las consecuencias derivadas de la estacionalidad de la producción, en la zona del Urabá (Colombia). Para ello, se evaluaron en el clon Williams (Musa AAA Simmonds), diferentes densidades de plantación $\left(2.000,2.500,3.000\right.$ y 3.500 plantas ha $\left.{ }^{-1}\right)$, distintos arreglos poblacionales (triángulo, rectángulo y doble surco) y un testigo relativo (1.700 plantas $\mathrm{ha}^{-1}$ en triángulo). El diseño utilizado fue de bloques completos al azar en arreglo factorial, de 4 × $3+$ 1 (densidades $\mathrm{x}$ arreglos + testigo). Se determinaron la altura y perímetro del pseudotallo, el número de hojas de siembra a cosecha, el índice de área foliar (IAF), el coeficiente de extinción de luz, el número de hijos y fases de desarrollo: días transcurridos a floración y cosecha. Se realizó un análisis de varianza general y otro excluyendo el testigo. Se aplicó la prueba de Tukey $(\mathrm{P}<0,05)$ a las variables cualitativas y se hicieron contrastes de polinomios ortogonales, para probar los efectos lineal y cuadrático del factor densidad de población. Los resultados indicaron que las altas densidades de plantación y los arreglos poblacionales tuvieron un efecto negativo sobre el perímetro del pseudotallo y la altura del hijo a parición, favorecieron el IAF, influyeron en el coeficiente de extinción, pero no afectaron el desarrollo de las plantas.

Palabras clave: Banano; Interceptación de luz; Competencia de plantas; Población de plantas.

\section{INTRODUCTION}

Banana is the most widely consumed tropical fruit of the world. Colombia ranks fourth among the exporting countries with 1,806,000 thousands of tons (Biswas \& Kumar, 2010; FAO, 2019); furthermore, it ranks third among the agricultural products most exported by Colombia after coffee and flowers (AUGURA, 2019). Banana yield in the Uraba region is dominated by climate seasonality, which determines two well-defined periods: A dry and productively limited first semester, followed by a rainy and oversupplied second semester (Toro et al. 2016). This, in turn, affects the behavior of international prices, which follow an inverse trend to that of fruit production (AUGURA, 2012), thus putting traditional banana production systems in disadvantage.

Establishing high density (HD) banana plantations is a cultivation practice that allows not only to increase productivity without affecting fruit quality, but also optimizing the use of natural resources (Gogoi et al. 2015; Hanuman Naik et al. 2016c); furthermore, the capacity of the culture system to suppress common weeds from tropical regions (Lanza et al. 2017) and reduce the severity of black Sigatoka disease, caused by Mycosphaerella fijensis (Barrera et al. 2016) is added. However, larger plant numbers take a toll on both light interception (as also affected by leaf area) and the passage of light through the canopy. This can be assessed through the light extinction coefficient (k), which usually ranges from 0.45 to 0.75 , thus constituting an indicator of light supply inside the production system (Stover, 1984). Densities above 5000 plants ha ${ }^{-1}$ usually determine intensities of 2500 lux, while 2500 plants ha ${ }^{-1}$ register 7200 average lux counts (Debnath et al. 2015). Leaf Area Index (LAI) being directly proportional to planting density (Rodríguez et al. 2007), values of 3.36 in this parameter are associated to 2500 plants ha ${ }^{-1}$, while records of 6.11 correspond to 6666 plants $\mathrm{ha}^{-1}$, which exerts a negative effect on the plantation already (Debnath et al. 2015).

Although Lecompte \& Pagès (2007) reported that shading reduced the number of primary roots derived from the corm by $12 \%$, they found no effect on the elongation rate, but on the density and diameter of the first order lateral roots, which were reduced by $32 \%$ and $14 \%$, respectively. Likewise, morphology, growth and productivity can be affected by varying photonic flow gradients (Siles et al. 2013). In addition, there is evidence that shading is positively related to leaf emission rate, leaf area, pseudostem perimeter and height, while fruit weight and quality are negatively affected (Sarrwy et al. 2012). In this same regard, however, Mustafa \& Kumar (2012) report $120 \mathrm{t} \mathrm{ha}^{-1}$ yields of good fruit quality at 4091 plants ha ${ }^{-1}$ (which is considered to be HD as also confirmed by Mahmoud (2013).

Considering the importance of banana cultivation and the need to make better use of the soil through larger plant populations, the current study intends to validate this alternative by evaluating its effect on the growth and development of the clone Williams established under different densities and spatial distributions.

\section{MATERIALS AND METHODS}

Research was conducted from 2015 to 2016 at La Tagua farm, which belongs to the company Bananeras de Urabá, located in the municipality of Turbo, Antioquia (Colombia). The experimental site is located at $07^{\circ} 53^{\prime} \mathrm{N} 76^{\circ} 41^{\prime} \mathrm{O}$, with an average temperature of $27^{\circ} \mathrm{C}$, $28 \mathrm{~m}$ asl, $85-90 \%$ relative humidity and average annual rainfall of $2700 \mathrm{~mm}$. All these features correspond to a very humid tropical forest climate (Belda et al. 2014). The soil exhibited clay loamy texture; $\mathrm{pH} 5.8$; organic matter (OM) content, $1.73 \%$; respective $\mathrm{Ca}$ and $\mathrm{Mg}$ levels of 8.9 and $4.11 \mathrm{cmolckg}^{-1} ; \mathrm{K}, 0.41 \mathrm{cmolckg}^{-1}$; P, 21.4mg kg $\mathrm{mg}^{-1}$ S, 5.67mg kg $\mathrm{m}^{-1}$ Z Zn, 2.0mg kg ${ }^{-1}$, B, 0.54mg kg Cation Exchange Capacity (CEC), 13.6 $\mathrm{cmolckg}^{-1}$; and an adequate relationship between bases. This information allowed defining the nutrition plan to meet the needs of the plantation, which was set up with in vitro propagated seedlings of the clone Williams (Musa AAA Simmonds), distributed according to the treatment plan (Table 1). Initial soil organic matter and P supplies conformed to crop requirements and soil analysis. The subsequent agronomic management was done according to the technical recommendations for each particular case.

The study was conducted under a randomized complete block design with 4 × 3 (four planting densities $\mathrm{x}$ three population arrangements) bifactorial arrangement, plus a control treatment, with three replicates per treatment. This resulted in 13 treatments featured by the combinations between the four planting densities 
Table 1. Treatments, planting densities and spatial arrangements in a banana plantation of the clone Williams (Musa AAA Simmonds).

\begin{tabular}{|c|l|l|}
\hline Treatment & Planting density $\left(\right.$ plants $\left.\mathbf{h a}^{-1}\right)$ & \multicolumn{1}{|c|}{ Spatial arrangements $(\mathbf{m})$} \\
\hline 1 & 1700 & Control $(2.7 \times 2.7)$ \\
\hline 2 & 2000 & Triangle $(2.3 \times 2.3)$ \\
\hline 4 & 2500 & Triangle $(2.15 \times 2.15)$ \\
\hline 5 & 3000 & Triangle $(1.95 \times 1.95)$ \\
\hline 6 & 3500 & Triangle $(1.8 \times 1.8)$ \\
\hline 7 & 2000 & Rectangle $(3.2 \times 1.57)$ \\
\hline 8 & 2500 & Rectangle $(2.8 \times 1.30)$ \\
\hline 9 & 3000 & Rectangle $(2.6 \times 1.20)$ \\
\hline 10 & 3500 & Rectangle $(2.4 \times 1.15)$ \\
\hline 11 & 2000 & Double row $(\mathrm{dp} * 1.0 \times \mathrm{dr} * * 3.3)$ \\
\hline 11 & 2500 & Double row $(\mathrm{dp} * 1.2 \times \mathrm{dr} * * 3.3)$ \\
\hline 12 & 3000 & Double row $(\mathrm{dp} 1.0 \times \mathrm{dr} 3.0)$ \\
\hline 13 & 3500 & Double row $(\mathrm{dp} 1.0 \times \mathrm{dr} 2.8)$ \\
\hline
\end{tabular}

* dp distance between plants $(\mathrm{m}),{ }^{* *} \mathrm{dr}$ distance between rows (m).

(2000, 2500, 3000 and 3500 plants $\left.\mathrm{ha}^{-1}\right)$ and the three arrangements (triangle, rectangle and double furrow), plus the relative control (1700 plants ha ${ }^{-1}$ under a triangular arrangement). Each experimental unit contained an approximate population of 26 plants of which we established the "useful plot" (four central plants). Growth and development variables were assessed following homonymous methodology as defined by Martínez \& Cayón (2011) for the clones Great Dwarf and Valery.

Plant height and pseudostem perimeter (m). Plant height was measured from the base at the junction of the corm with the pseudostem to the armpit of the last leaf. The circumference was taken at $1 \mathrm{~m}$, height from the ground at the time of harvest.

Number of leaves to harvest (No). The total number of leaves produced by the plant was counted both at flowering and harvest. Leaf area $\left(\mathrm{cm}^{2}\right)$. This parameter was estimated as the product of leaf length, maximum width and the constant 0.876 (Cogliatti et al. 2010). The average foliar area of a leaf was multiplied by the number of leaves present on the plant, during flowering.

Leaf area index (LAI). It was calculated following methodology by Barrera et al. (2010), based on foliar area and planting distance, during the flowering period of the crop.

Light extinction coefficient (k). This value was assessed at each stratum ( $1 \mathrm{~m}$ above the ground and at the middle and upper layers of the foliage), in the development phases floral differentiation, flowering and harvest, following the model of Monsi and Saeki for continuous canopies, which is based on the Lambert-Beer Law (Cabezas \& Corchuelo, 2005).
Floral differentiation (days). This is a time measurement which goes from the moment of planting to that of floral differentiation, when the basal lobes of the leaf flag are asymmetric.

Flowering (days). Time elapsed from the production of the first true leaf (i.e., the one that already exhibits the morphological characteristics of the clone) to the emergence of the inflorescence.

Harvest (days). Time elapsed from the moment of the emergence of the inflorescence to the harvest of the fruit bunch.

An overall analysis of variance was performed for all treatments in order to determine their effects on the studied variables. An additional analysis of variance contemplated only the two factors in question (densities and population arrangements), in order to both determine their individual effects on the variables and assess their interactions. Orthogonal polynomial contrasts were also performed to test the linear and quadratic effects of the planting density factor. In addition, polynomial regression models were tested on all treatments, including the control one, in order to estimate the best fit. A Tukey test at 5\% was applied to the spatial arrangement factor, since it is qualitative in nature, and thus exhibits no group structure.

\section{RESULTS AND DISCUSSION}

Growth. The analysis of variance (both including and excluding the control treatment) reported significant effects of planting density and spatial arrangement on the studied growth parameters of the clone Williams. The variables not were affected by the treatments and no significant effect resulted from the interaction between arrangement A and planting density B. The Tukey test $(\mathrm{p} \leq 0.05)$ revealed that pseudostem perimeter, sucker height at flower shoot 
emergence, LAI and number of leaves at harvest were significantly influenced by the treatments (Table 2).

The response of pseudostem perimeter to planting density fits a quadratic regression model $\left(\mathrm{R}^{2}=0.99\right)$. The values of this parameter peaked at low densities (2000 plants $\mathrm{ha}^{-1}$ ) and decreased notably at HD (Figure 1a). The development of this organ is affected by HD through competition between plants, which induces a photomorphogenic action on the part of photoreceptors such as phytochromes, cryptochromes and phototropins (Franklin, 2016). Regarding the thickness of the pseudostem, it is important to highlight its strong association with the vigor and productivity of banana plants (Kumar \& Pandey, 2010). In addition, the root system is reduced by increasing planting densities (Lecompte \& Pagès, 2007; Chaudhuri \& Baruah, 2010), which affects nutrient absorption and plant anchoring (Mustafa \& Kumar, 2012). Pseudostem thickness reduction with increased planting density has also been attributed to competition for light and soil nutrients (Chaudhuri \& Baruah, 2010). More recently, Patel et al. (2018) found significant effects on the height of the pseudostem by providing nutrients and greater spacing between the banana plants cv. Grand Naine. Nonetheless, Delgado et al. (2008) and Smith et al. (2010) did not find significant effects after conducting similar studies in other commercial musaceaes planted at densities of 2500 plants ha $^{-1}$.

As to the number of leaves at harvest, the highest count (9.0 leaves plant ${ }^{-1}$ ) was recorded under the triangular arrangement, thus exceeding by $9.7 \%$ the record of the double row arrangement, which was 8.3 leaves plant ${ }^{-1}$. For its part, the rectangular arrangement $(8.5$ leaves plant ${ }^{-1}$ ) did not differ from the triangular and double row arrangements (Figure 1b). In analyzing the spatial arrangements under each planting density, the highest number of leaves corresponded to 3000 plants ha ${ }^{-1}$ under the triangular arrangement (9.0 leaves plant $^{-1}$ ), which exceeded by $30.3 \%$ the record of the 2500 plants $\mathrm{ha}^{-1}$ density under the rectangular arrangement. The rest of the treatments did not differ from the triangular arrangement (Table 2). The triangular arrangement is likely to favor the spatial distribution of the leaves, thus allowing greater light uptake (Chaudhuri \& Baruah, 2010). These authors attributed larger numbers of leaves at flower shoot emergence and harvest under low planting densities to better exposure to light.

Main sucker height at flower shoot emergence as a function of planting density was partially explained by a quadratic regression model $\left(R^{2 .}=0.42\right)$, wherein the maximum records corresponded to the lowest planting densities (about 2000 plants $\mathrm{ha}^{-1}$ ), the increase of which determined a reduction in the parameter (Figure 1a). According to the means test, maximum main sucker height was recorded at a density of 2500 plants ha ${ }^{-1}$ under the double furrow arrangement $(111.22 \mathrm{~cm})$, followed by 2500 and 3000 plants ha ${ }^{-1}$ under the triangular arrangement, and by 3500 plants $\mathrm{ha}^{-1}$ under the rectangular one, both of which behaved similarly by reaching an average height of $21.79 \mathrm{~cm}$. The rest of the treatments were statistically similar to the control treatment.

Table 2. Effect of planting density and spatial arrangement on the growth of banana clone Williams (Musa AAA Simmonds).

\begin{tabular}{|c|l|c|c|c|c|c|c|}
\hline Treatment & Spatial arrangement & $\begin{array}{c}\text { Planting density } \\
\left(\mathbf{p l a n t s ~ h a ~}^{-1} \text { ) }\right.\end{array}$ & $\mathbf{P H}$ & $\mathbf{N L P H}$ & MSHFSE & LAI & $\boldsymbol{k}$ \\
\hline 1 & Triangle & 1700 & $200.4 \mathrm{c}$ & $8.89 \mathrm{ab}$ & $51.67 \mathrm{ab}$ & $1.83 \mathrm{~d}$ & $0.55 \mathrm{~b}$ \\
\hline 2 & Triangle & 2000 & $225.8 \mathrm{ab}$ & $8.55 \mathrm{ab}$ & $73.78 \mathrm{ab}$ & $2.09 \mathrm{bcd}$ & $0.85 \mathrm{a}$ \\
\hline 3 & Triangle & 2500 & $210.6 \mathrm{abc}$ & $9.44 \mathrm{ab}$ & $20.22 \mathrm{~b}$ & $2.03 \mathrm{~cd}$ & $0.81 \mathrm{a}$ \\
\hline 4 & Triangle & 3000 & $208.1 \mathrm{bc}$ & $9.55 \mathrm{a}$ & $20.93 \mathrm{~b}$ & $3,29 \mathrm{bcd}$ & $0.68 \mathrm{ab}$ \\
\hline 5 & Triangle & 3500 & $212.9 \mathrm{abc}$ & $8.67 \mathrm{ab}$ & $62.50 \mathrm{ab}$ & $3.62 \mathrm{ab}$ & $0.67 \mathrm{ab}$ \\
\hline 6 & Rectangle & 2000 & $229.8 \mathrm{ab}$ & $8.44 \mathrm{ab}$ & $51.83 \mathrm{ab}$ & $2.42 \mathrm{bcd}$ & $0.55 \mathrm{~b}$ \\
\hline 7 & Rectangle & 2500 & $213.6 \mathrm{abc}$ & $7.33 \mathrm{~b}$ & $80.66 \mathrm{ab}$ & $2.61 \mathrm{bcd}$ & $0.62 \mathrm{ab}$ \\
\hline 8 & Rectangle & 3000 & $219.1 \mathrm{abc}$ & $9.33 \mathrm{ab}$ & $35.67 \mathrm{ab}$ & $3,34 \mathrm{abcd}$ & $0.53 \mathrm{~b}$ \\
\hline 9 & Rectangle & 3500 & $231.9 \mathrm{ab}$ & $8.78 \mathrm{ab}$ & $24.22 \mathrm{~b}$ & $4.34 \mathrm{a}$ & $0.75 \mathrm{ab}$ \\
\hline 10 & Double row & 2000 & $216.6 \mathrm{abc}$ & $8.34 \mathrm{ab}$ & $40.22 \mathrm{ab}$ & $2.04 \mathrm{~cd}$ & $0.58 \mathrm{~b}$ \\
\hline 11 & Double row & 2500 & $234.7 \mathrm{a}$ & $8.22 \mathrm{ab}$ & $111.22 \mathrm{a}$ & $2.71 \mathrm{bcd}$ & $0.53 \mathrm{~b}$ \\
\hline 12 & Double row & 3000 & $222.4 \mathrm{abc}$ & $8.00 \mathrm{ab}$ & $49.00 \mathrm{ab}$ & $3.52 \mathrm{abc}$ & $0.67 \mathrm{ab}$ \\
\hline 13 & Double row & 3500 & $227.4 \mathrm{ab}$ & $8.44 \mathrm{ab}$ & $37.89 \mathrm{ab}$ & $3.50 \mathrm{abc}$ & $0.63 \mathrm{ab}$ \\
\hline
\end{tabular}

Numbers with the same letters do not differ statistically according to the Tukey test $(\mathrm{p}=0.05)$.

PH = Plant height at flowering; NLPH = Number of leaves at harvest; MSHFSE = Main sucker height at flower shoot emergence; LAI $=$ Leaf area index, $k=$ Light extinction coefficient at flowering. 

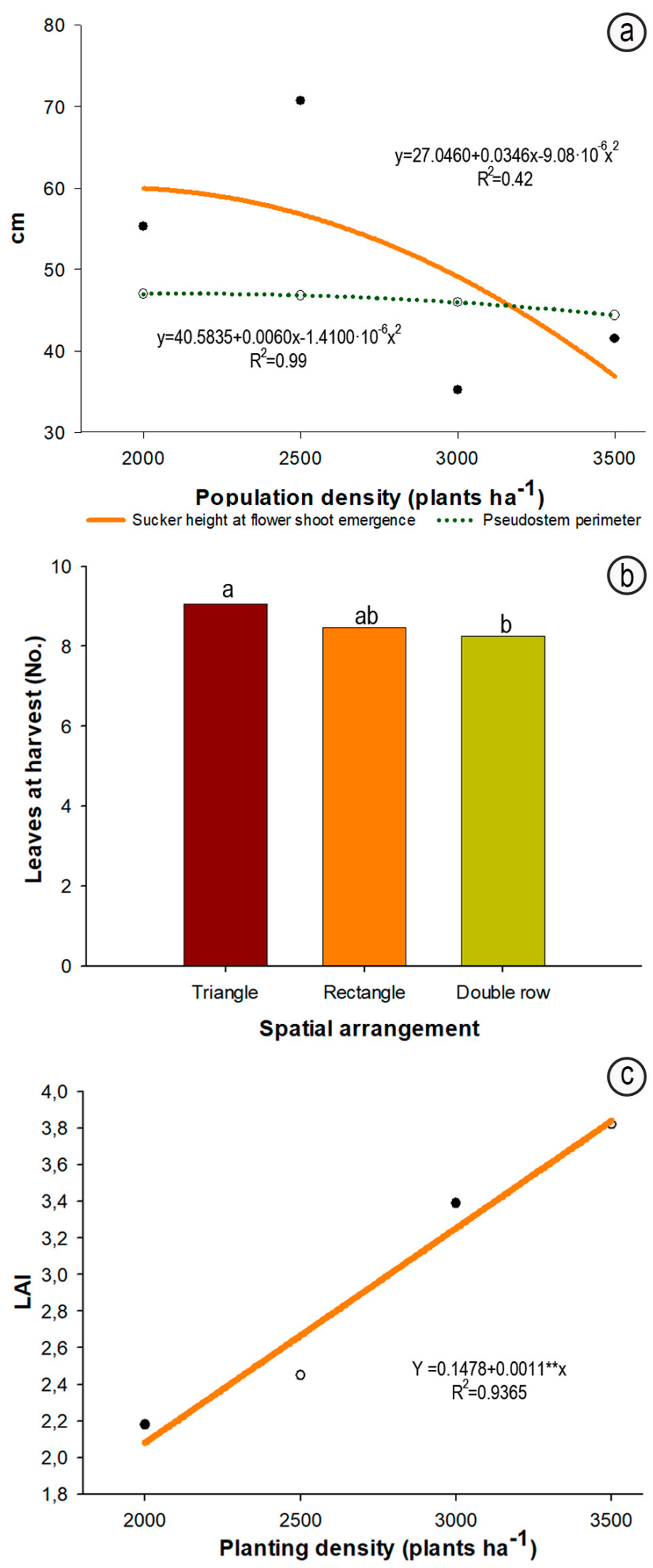

Figure 1. Response variables to different planting densities in the banana clone Williams (Musa AAA Simmonds). a) Pseudostem perimeter (Significant differences at $10 \%(\mathrm{p}=0.05-0.10) ; \mathrm{R}^{2}$ : Coefficient of determination); b) Number of leaves (Mean values with the same letters do not differ statistically according to Tukey's test $(p=0.05))$; c) Leaf area index -LAI. 
This parameter is essential to decide on the appropriate density when trying to establish the crop in consecutive production cycles. The results obtained in this study for densities below 2500 plants $\mathrm{ha}^{-1}$ could be of interest to establish the optimum density when using the method of several consecutive cycles.

Our analyses would suggest that in the environmental conditions of the Urabá, the cultivation system in HD at a second cycle is feasible, because the effect of the treatments, despite presenting statistical differences in the height of the return sucker, this is adequate, as long as the price opportunities in the market are competitive, or the fruit is used to win quotas for exporting boxes, since the same number of boxes delivered in the first semester (good price), is received in the second semester, with the same commercial value and number of boxes, because as plantation density increases, it contributes to increasing productivity per hectare (Barrera et al. 2020). These results are harmony with those obtained by Chaudhuri \& Baruah (2010) who found that planting density significantly affected both the number of suckers and their production. This can be attributed to incident radiation, especially for the 3000 plants $\mathrm{ha}^{-1}$ density under the triangular arrangement. However, most of the treatments exhibited a similar behavior to that of the control (Table 2). In this respect, Stover (1984) reports that an optimum range for sucker development is $14-16 \%$ of the photosynthetically active radiation entering the plantation. Likewise, the vegetative growth of banana plants in terms of pseudostem height and circumference is positively influenced by reduced planting distances (Palkar et al. 2012), mainly due to mutual shading, which affects growth rate through competition for light (Gliessman, 1998; Nalina et al. 2000).

LAI correlated directly with planting density, as explained by the linear regression model $\left(\mathrm{R}^{2}=0.96\right)$ fit by the relation between these parameters (Figure 1c), which is consistent with the results of Chaudhuri \& Baruah (2010). The highest LAI value (4.34) was obtained with the 3500 plants $\mathrm{ha}^{-1}$ density under the rectangular array, followed by that of the 3500 plants ha ${ }^{-1}$ density under the triangular arrangement. For its part, the lowest LAI value was registered by the control treatment (Table 2). The current LAI values are similar to the 3.49 record found by Rodríguez et al. (2007) for the Great Dwarf clone, exception made of their 3500 plants ha ${ }^{-1}$ density record under a rectangular arrangement. On the other hand, the elevated LAI values observed for the 3500 plants ha ${ }^{-1}$ density under the rectangular arrangement can overcome the optimal LAI threshold. Under these conditions, 90\% of the incident radiation is intercepted by the canopy (Turner et al. 2007), which is scarcely beneficial for the plant and tends to hinder its productivity. However, in the opinion of Smith et al. (2010), this situation is likely to increase unit area yield.

The light extinction coefficient $(k)$ was influenced by both planting density and spatial arrangement (Table 2 and Figure 2). With the exception of the 2000 and 2500 plants ha ${ }^{-1}$ densities under the triangular arrangement, all other treatments registered values within the 0.45 to 0.75 range, as previously reported for banana by Stover (1984). The value of $k$ depends on plant architecture and leaf position, angle and orientation (Chaves et al. 2009). The differences observed in the current study confirm the influence of the plantation system, in agreement with Pilau \& Angelocci (2015). However, it should be noted that the reduction in the value of $k$ does not necessarily increase productivity, under the assumption that the photosynthetic capacity is also increased. This is so because the latter also depends on other factors such as sink force, $\mathrm{CO}_{2}$ availability, leaf - sink distance, leaf age and stressing situations (Guevara \& Rodríguez, 2006).

The development-related variables, namely days to flower differentiation (DFD), days to flowering (DF), and days from flowering to harvest $(\mathrm{DFH})$ were not influenced $(\mathrm{P}>0.05)$ by planting arrangement, planting density or their interaction. The results confirm that the evaluated densities and arrangements did

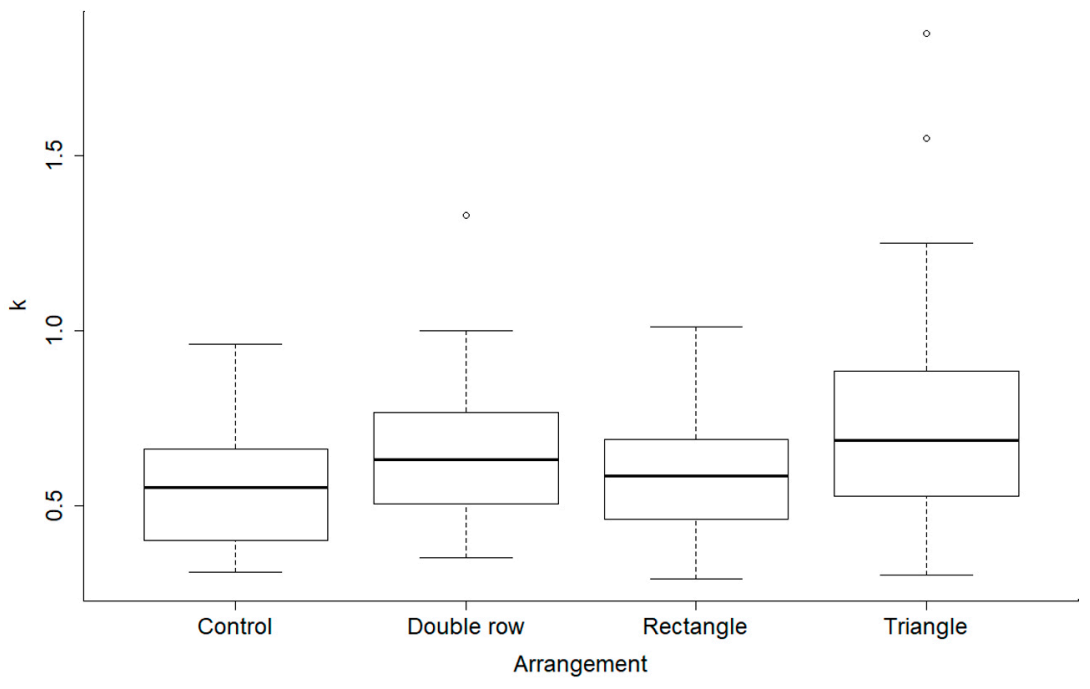

Figure 2. Influence of spatial arrangement on the light extinction coefficient in banana clone Williams (Musa AAA Simmonds). 
not compromise the length of the growing period or the duration of the studied plant development stages, namely DTF, FT and HT. In this regard, the average vegetative cycle of the banana crop in the evaluated arrangements was 219, 304, 307 and 308 days for the control, triangular, rectangular and double furrow arrangements, respectively, at all the evaluated planting densities (Figure 3). About this aspect, Martínez \& Cayón (2011) recorded similar data for the clone Gran Enano in the Urabá Antioqueño region (i.e., the Urabá region of the Department of Antioquia, Colombia). However, those data are different from those indicated by Chaudhuri \& Baruah (2010) and Hanuman Naik et al. (2016a; b), which showed significant effects of high planting densities on crop development and new succession buds. These results are important because in the event of an extension of the reproductive cycle, the production costs would also rise through increased agricultural labor and a more expensive phytosanitary control of Mycosphaerella fijiensis, for which a higher number of fungicide application cycles would be necessary.

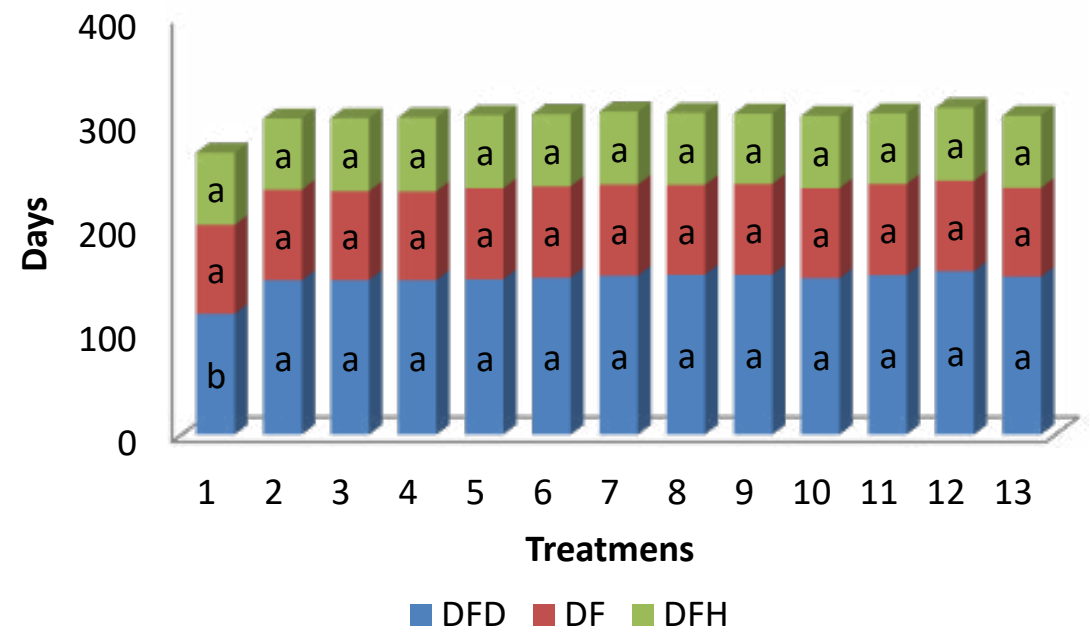

Figure 3. Development phases of the banana clone Williams (Musa AAA Simmonds), in different planting densities and population arrangements. DFD: days to flower differentiation. DF: days to flowering. DFH: days from flowering to harvest.

Mean values with the same letters do not differ statistically according to Tukey's test $(p=0.05)$.

In conclusion, the pseudostem perimeter and main sucker height at the time of flower shoot emergence were negatively affected by increased planting densities under the different spatial arrangements studied in this research and the triangular spatial arrangement was found to increase the number of leaves at harvest, while the double row arrangement reduced this parameter. In the same way, the leaf area index showed a direct correlation with planting density, which, in turn, modified the light extinction coefficient inside the canopy. And finally, neither high planting density nor spatial arrangement influenced the duration of the phenological stages of the studied banana crop.

Conflicts of interest: The manuscript was prepared and reviewed with the participation of all the authors, who declare that no conflict of interest that threatens the validity of the results presented.

\section{REFERENCES}

1. ASOCIACIÓN DE BANANEROS DE COLOMBIA, AUGURA. 2012. Coyuntura bananera colombiana. Unidad de Estadística y Análisis Económico. Departamento de Sistemas. Medellín - Colombia. 32p.
2. ASOCIACIÓN DE BANANEROS DE COLOMBIA, AUGURA. 2019. Coyuntura bananera colombiana. Unidad de Estadística y Análisis Económico. Departamento de Sistemas. Medellín - Colombia. 47p.

3. BARRERA, J.; BARRAZA, F.; CAMPO, R. 2016. Shadow effect on black sigatoka (Mycosphaerella fijiensis morelet) in plantain cultivation cv. Harton (Musa AAB Simmonds). Rev. U.D.C.A Act. \& Div. Cient. (Colombia). 19(2):317-323. https://doi.org/10.31910/rudca.v19.n2.2016.85

4. BARRERA, J.; CARTAGENA, J.; NANCLARES, O. 2020. Influence of high planting densities and arrangements on yield and fruit development of Musa AAA Simmonds. Acta Agronómica (Colombia). 69(1):46-53. https://doi.org/10.15446/acag.v69n1.79834

5. BARRERA, J.; SUAREZ, D.; MELGAREJO, L.M. 2010. Análisis de crecimiento en las plantas. En: Melgarejo, L.M. (ed.). Experimentos en Fisiología Vegetal. Ed. Universidad Nacional de Colombia (Bogotá). p.25-38. 
6. BELDA, M.; HOLTANOVÁ, E.; HALEENKA, T.; KALVOVÁ, J. 2014. Climate classification revisited: from Köppen to Trewartha. Climate Research (Czech Republic). 59(1):1-13. https://doi.org/10.3354/cr01204

7. BISWAS, B.C.; KUMAR, L. 2010. High Density Planting: Success Stories of Banana Farmers. Fertiliser Marketing News (India). 41(6):3-10.

8. CABEZAS, M.; CORCHUELO, G. 2005. Estimación de la interceptación de la radiación solar en papa criolla (Solanum phureja Juz. et Buk.) en tres localidades colombianas. Agronomía Colombiana (Colombia). 23(1):62-73.

9. CHAUDHURI, P.; BARUAH, K. 2010. Studies on planting density in banana cv. 'Jahaji' (AAA). Indian J. Hill Farming. (India). 23(2):31-38.

10. CHAVES, B.; CAYÓN, G.; JONES, J. 2009. Modeling plantain (Musa AAB Simmonds) potential yield. Agronomía Colombiana. 27(3):359-366.

11. COGliatTi, D.; CATAldi, M.; IGLESIAS, F. 2010. Estimación del área de las hojas en plantas de trigo bajo diferentes tipos de estrés abiótico. Agriscientia (Argentina). 27:43-53.

12. DEBNATH, S.; BAURI, F.; BANDYOPADHYAY, B.; MISRA, D.; MANDAL, K.; MURMU, I.; PATIL, P. 2015. Identification of optimum leaf area index (LAI) for high density planting of banana cv. Martaman in Gangetic Alluvium region of West Bengal. J. Crop and Weed (India). 11(2):63-66.

13. DELGADO, E.; GÓMEZ, N.; GONZÁLEZ, O.; MARÍN, C. 2008. Evaluación a nivel de finca del efecto de la alta densidad de siembra en plátano (Musa AAB cv. Subgrupo plátano Hartón), municipio Obispo, Barinas, Venezuela. Rev. Fac. Agron. (Venezuela). 25:603-616.

14. FOOD AND AGRICULTURE ORGANIZATION OF THE UNITED NATIONS, FAO. 2019. Banana Market Review. Preliminary results. (Italy). 14p.

15. FRANKLIN, K. 2016. Photomorphogenesis: Plants feel blue in the shade. Current Biology (United Kingdom). 26:R1272-R1296.

https://doi.org/10.1016/j.cub.2016.10.039

16. GLIESSMAN, S.R. 1998. Agroecology: ecological processes in sustainable agriculture. Chelsea, Michigan, Ann Arbor Press. (USA). 400p.

17. GOGOI, B.; KHANGIA, B.; BARUAH, K.; KHOUND, A. 2015. Effect of high density planting and nutrient management on growth and yield of banana cv. Jahaji (Musa, AAA). Internal J. Agriculture Innovations and Research (India). 3(5):1364-1368. https://doi.org/10.5958/2249-5258.2015.00036.6

18. GUEVARA, E.; RODRÍGUEZ, W. 2006. Arquitectura vegetal e interceptación de la luz. Universidad de Costa Rica (San José de Costa Rica). 96p.

19. HANUMAN NAIK, M.; VANAJALATHA, K.; PRASANTH, P.; KIRAN A.; KUMAR.; NAIDU, M.M. 2016a. Role of high density planting and fertigation on growth, yield and quality of banana (Musa acuminata L.) cv. Grand Naine of ratoon crop. Internal J. Advanced Research (India). 4(10):2151-2159.

https://doi.org/10.21474/IJAR01/2034

20. HANUMAN NAIK, M.; VANAJALATHA, K.; PRASANTH, P.; MUTYALA, M. 2016b. Studies on the effect of high density planting and fertigation on vegetative growth, yield and quality of banana (Musa acuminata L.) cv. Grand Naine of main crop. Internal J. Current RESEARCH. (India). 8(11):42010-42015.

21. HANUMAN NAIK, M.; VANAJALATHA, K.; RAMESH, T.; PRASANTH, P. 2016c. Impact of high density planting and fertigation on leaf and soil nutrient status of banana (Musa acuminata L.) cv. Grand Naine for main and ratoon crop. Plant Archives (India). 16(2):839-844.

22. KUMAR, D.; PANDEY, V. 2010. Relationship of pseudostem cross-sectional area with bunch weight, fruit quality and nutrient status in banana cv. Rasthali (pathkapoora - AAB). Indian J. Horticulture. 67(1):26-29.

23. LANZA, T.R.; MACHADO, A.F.L.; MARTELLETO, L.A.P. 2017. Effect of planting densities of "BRS princess" banana tree in the suppression of weeds. Planta Daninha. 35:e017162958.

https://doi.org/10.1590/S0100-83582017350100054

24. LECOMPTE, F.; PAGÈS, L. 2007. Apical diameter and branching density affect lateral root elongation rates in banana. Environmental and Experimental Botany. (Netherlands). 59:243-251.

25. MAHMOUD, H. 2013. Effect of different levels of planting distances, irrigation and fertigation on yield characters of main banana crop cv. Grand Naine. Global J. Plant Ecophysiology (USA). 3(2):115-121.

26. MARTÍNEZ, A.M.; CAYÓN, D.G. 2011. Dinámica del crecimiento y desarrollo del banano (Musa AAA Simmonds cvs. Gran Enano y Valery). Rev. Fac. Nac. Agron. Medellín. (Colombia). 64(2):6055-6064. 
27. MUSTAFA, M.; KUMAR, V. 2012. Banana production and productivity enhancement through spatial, water and nutrient management. J. Horticultural Science (Czech Republic). 7(1):1-28.

28. NALINA, L.; KUMAR, N.; SATHIAMOORTHY, S.; MUTHUVEE, P. 2000. Effect of nutrient levels on bunch characters of banana cv. Robusta under high density planting system. South Indian J. Hort. (India). 48(1-6):1822.

29. PALKAR, S.; PATEL, N.; MHETRE, D.; MANDALIK, G. 2012. Effect of high density planting on the growth and development characters of the banana (Musa paradisiaca L.) cv. Grand Naine. Internal Journal of Agricultural Sciences (USA). 8(1):201-204.

30. PATEL, M.J.; SITAPARA, H.H.; SHAH, N.I.; PATEL, H.R. 2018. Effect of different levels of planting distance and fertilizers on growth, yield andquality of banana cv. Grand Naine. J. Pharmacognosy and Phytochemistry. 7(2):649653.

31. PILAU, F.; ANGELOCCI, L. 2015. Leaf area and solar radiation interception by orange tree top. Bragantia (Brazil) 74(4):476-482. http://dx.doi.org/10.1590/1678-4499.0130

32. RODRÍGUEZ, W.; ARAYA, J.; PÉREZ, L. 2007. Efecto del arreglo espacial y la densidad de siembra sobre la estructura y eficiencia del dosel, el crecimiento y la producción del banano (Musa AAA cv. Willians). Corbana (Costa Rica). 33(60):1-14.
33. SARRWY, S.; MOSTAFA, E.; HASSAN, H. 2012. Growth, yield and fruit quality of Williams banana as affected by different planting distances. Internal J. Agricultural Research. (India). 7(5):266-275.

34. SILES, P.; BUSTAMANTE, O.; VALDIBIA, E.; BURKHARDT, J.; STAVER, C. 2013. Photosynthetic Performance of banana ('Gros Michel', AAA) under a natural shade gradient. Acta Horticulturae (USA). 886(1):71-77. https://doi.org/10.17660/ActaHortic.2013.986.5

35. SMITH, E.; VELÁSQUEZ, M.; ZULUAGA, L.; VALERIN, J. 2010. Efecto de la densidad de población sobre el crecimiento y producción de plantas en primera generación de banano dátil (Musa AA). Agronomía Costarricense (Costa Rica). 34(1):77-83.

36. STOVER, R.H. 1984. Canopy management in Valery and Grand Nain using leaf area index and photosyntetically active radiation measurements. Fruits (USA). 39:89-93.

37. TORO, A.; ARTEAGA, R.; VÁZQUEZ, M.; IBÁÑEZ, L. 2016. Requerimientos de riego y predicción del rendimiento en el cultivo de banano mediante un modelo de simulación en el Urabá antioqueño, Colombia. Tecnología y Ciencias del Agua (México). 7(6):105-122.

38. TURNER, D.; FORTESCUE, J.; THOMAS, D. 2007. Environmental physiology of the bananas (Musa spp.). Braz. J. Plant Physiol. (Brazil). 19(4):463-484. https://doi.org/10.1590/S1677-04202007000400013 